\title{
CONTROLE DE CONSTITUCIONALIDADE, NEOCONSTITUCIONALISMO E RELATIVISMO DAS DECISÕES JUDICIAIS
}

Tiago Bruno Bruch*1

Resumo: $O$ artigo analisa a relação do controle judicial de constitucionalidade com o relativismo das decisões judiciais no Brasil. Trata-se de uma pesquisa qualitativa, realizada por meio de método dedutivo, com a técnica de pesquisa bibliográfica e documental. O texto inicia com descrição dos modelos de controle de constitucionalidade, passando, após, a analisar o neoconstitucionalismo e sua conexão com o relativismo das decisões judiciais. $\mathrm{Na}$ sequência apresenta-se o modelo de garantismo jurídico como um contraponto a essa conjuntura, a partir de uma crítica à ampliação e abertura dos métodos interpretativos, rejeitando a fundamentação baseada nas convicções pessoais dos magistrados.

Palavras-chave: Controle de constitucionalidade; neoconstitucionalismo; relativismo; fundamentação jurídica; constitucionalismo garantista

\section{CONSTITUTIONALITY CONTROL, NEOCONSTITUTIONALISM AND RELATIVISM OF JUDICIAL DECISIONS}

\begin{abstract}
The article analyzes the relationship between judicial constitutionality control and the relativism of judicial decisions in Brazil. It is a qualitative research, carried out through a deductive method, with the technique of bibliographic and documentary research. The text begins with a description of the constitutionality control models, and then goes on to analyze neoconstitutionalism and its connection with the relativism of judicial decisions. Following, the Legal Guarantism model is presented as a counterpoint to this situation, criticizing the

\footnotetext{
1 *Mestrando e bolsista institucional do programa de pós-graduação em Direito e Sociedade da Universidade La Salle, em Canoas/RS, vinculado à linha de pesquisa Sociedade e Fragmentação do Direito. Bacharel em Direito pela Universidade do Vale do Taquari. Analista Judiciário do Tribunal Regional Federal da $4^{a}$ Região. Lattes: http://lattes.cnpq.br/4175098148498989 . iD ORCID: http://orcid.org/0000-0002-6586-3697 . Email: tiagobruch@gmail.com . Endereço postal: Rua Otávio F. Caruso da Rocha, 300, Porto Alegre, RS, 90010395.
} 
expansion and opening of interpretative methods, rejecting the reasoning based on judges' personal convictions.

Keywords: Constitutionality control; neoconstitutionalism; relativism; legal reasoning; Legal Guarantism

\section{CONSIDERAÇÕES INICIAIS}

O Direito - concebido como conjunto de normas e princípios que visa a regular a vida em sociedade - compreende uma hierarquia de suas fontes de modo a viabilizar a integração do sistema jurídico. No topo dessa hierarquia, desde que foram lançadas as sementes do positivismo, está a Carta Magna, Lei Maior, ou, modernamente chamada, Constituição de cada Estado. E é dela própria que emana o princípio da supremacia da Constituição, segundo o qual nenhuma lei, decreto ou ato normativo pode contrariar as suas disposições.

Na prática, entretanto, o Legislador, a Administração Pública, as pessoas naturais e jurídicas e o próprio Poder Judiciário são passíveis de criar ou cometer atos que violem o texto constitucional. Em grande parte das vezes, esses atos, ainda que afrontem a norma superior, são eficazes e produzem jurídicos e fáticos efeitos até que prove e se declare que são nulos justamente por serem inconstitucionais.

Partindo desse pressuposto, a fim de remediar ou evitar as violações a seu texto, e, assim, manter a ordem jurídica natural, a Carta Magna prevê mecanismos para fazer cessar os efeitos de uma norma violadora. A estes institutos de defesa da Constituição, chama-se controle de constitucionalidade.

Independentemente da seara em que atua o operador jurídico, está presente o direito constitucional e qualquer que seja a legislação, ato ou norma em cotejo deverá ser realizado um esforço hermenêutico para se verificar sua conformidade com os ditames da Constituição, sob pena de nulidade. Ademais, são recorrentes as ações que questionam a validade de atos em face da Lei Maior - é o que se depreende dos noticiosos, por exemplo. Na atual conjuntura, portanto, além de o operador verificar por si a conformidade constitucional, ele deve ser capaz de interpretar os entendimentos e os posicionamentos dos tribunais, mormente os do Supremo Tribunal Federal, porque, muitas vezes, o teor dessas decisões repercutirá sobre todas as lides relacionadas. Evidente, portanto, a pertinência da temática. 
O presente artigo pretende relacionar o controle judicial de constitucionalidade, decorrente da supremacia da constituição, no modelo do neoconstitucionalismo e também do constitucionalismo garantista. Além de se fazer um resgate histórico dos institutos, pretendese analisar a problemática da utilização de argumentos não jurídicos (entenda-se: não legislados) como parâmetro de (in)validade das normas e para julgar casos concretos.

A pesquisa, quanto à abordagem, será qualitativa, que tem como característica o aprofundamento no contexto estudado e a perspectiva interpretativa desses possíveis dados para a realidade, conforme esclarecem Mezzaroba e Monteiro (2009). Para obter a finalidade desejada pelo estudo, será empregado o método dedutivo, cuja operacionalização se dará por meio de procedimentos técnicos baseados na doutrina, legislação e jurisprudência, relacionados ao nascimento e desenvolvimento do Estado Constitucional e os três principais modelos de controle de constitucionalidade, passando pela evolução das constituições brasileiras, chegando-se ao controle concentrado de constitucionalidade na forma em que é previsto pela Carta de 1988.

Assim, na primeira parte deste artigo, será delineada a supremacia da Constituição; num segundo momento tratar-se-á do controle judicial de constitucionalidade, culminando em sua análise a partir do modelo de neoconstitucionalismo e do modelo garantista.

\section{CONSTITUCIONALISMO E SUPREMACIA DA CONSTITUIÇÃO}

O Estado como é concebido na contemporaneidade - através do polinômio povo, território e poder soberano -, conforme ensina Bastos (2002), tem suas raízes na Europa a partir da Idade Moderna. Desde a queda do Império Romano até o fim da Idade Média, não existiram as figuras de um grupo de pessoas que se identifica como pertencente a uma nação e, muito menos, um poder central dotado de soberania. Em verdade, os reis eram figuras simbólicas às quais os senhores feudais eram vinculados quase que exclusivamente pela tradição e honra (relações de suserania e vassalagem); nesse contexto, cada feudo era praticamente autônomo em relação aos demais para definir sua moeda, unidades de medida, autorizações de comércio, leis e julgamentos. Destarte, no medievo, também não se podia definir claramente a extensão e população de um reino ou feudo, uma vez que cada nobre detinha competência para autodesignar seus domínios. 
Em contraposição à sociedade feudal, no século XVI, surge a figura do Estado Nacional Absolutista. No início da Idade Moderna, enquanto a Europa ainda se recuperava da Peste Negra, irromperam diversas revoltas religiosas, políticas e sociais, como o Renascimento científico e artístico, o início das navegações oceânicas, a descoberta da América e a Reforma Protestante. Tais mudanças provocaram uma insegurança generalizada, em relação à qual as estruturas do feudalismo eram impotentes; logo, "urgia o surgimento de um poder que se colocasse acima das facções em pugna" (BASTOS, 2002, p. 45). Nesse ínterim, a nobreza feudal abriu mão de seu poder para tornar o rei soberano e acima das próprias leis, visando a repelir as ameaças do exterior e a subjugar as existentes no âmbito interno. Para fins de organização, mobilização e legitimação do poder régio foram traçados limites territoriais entre os domínios de um rei em relação aos de outro, de modo que as gentes inseridas nesse território deviam obediência ao respectivo monarca.

O modelo de Estado Absolutista centraliza o poder e a soberania estatais na figura do rei. "O poder é absoluto, porque cabe ao rei dispor de assuntos da soberania, como legislar, declarar a guerra e firmar a paz, decidir em última instância as controvérsias entre os súditos, nomear magistrados e tributar" (BODIN apud BRANCO; MENDES, 2012, p. 45). A expressão máxima desse modelo é a frase "L'État c'est moi" (em português: O Estado sou eu) atribuída ao Rei Luís XIV, da França.

O Estado Absolutista traz como inovação, na visão de Morais e Streck (2006), a criação do direito público. No modelo de produção feudal, a terra e as estruturas jurídicas, bem como as milícias, efetivamente pertencem ao nobre (relação de direito privado); por seu turno, no Estado Absolutista, embora o rei exerça seu domínio sem responsabilidade alguma, ele representa e administra os interesses e os bens do Reino ou Estado (há distinção entre os bens particulares do rei e os do Reino).

O Estado Constitucional, mais precisamente o Estado Liberal Constitucional, segundo afirma Canotilho (2002), é o que emerge da Independência dos EUA de 1776 e da Revolução Francesa de 1789. Na verdade, essas revoluções são o clímax decorrente das insatisfações do povo e da burguesia com a monarquia absolutista, que, desde sua consolidação no poder, mantinha-se inflexível frente às mudanças sociais. Ato contínuo, visando instituir um modelo diferente de sociedade, Estados Unidos e França promulgaram suas constituições em 1787 e 1791, respectivamente. 
Durante os séculos XVII e XVIII, pensadores iluministas como Locke, Voltaire, Rousseau e Montesquieu, lançaram as bases ideológicas de liberdade, igualdade e fraternidade (mote da Revolução Francesa). Mais do que isso, esses filósofos defendiam publicamente a laicidade do Estado, o direito à propriedade privada, o sufrágio universal e a tripartição e separação dos Poderes. A grande maioria desses preceitos norteiam os mais variados ordenamentos jurídicos até os dias de hoje. Entretanto, no afã de suplantar o Ancien Régime (absolutismo monárquico), Branco e Mendes (2012, p. 49), sustentam que os franceses deram preponderância ao Legislativo:

[...] Opunham-se uma linha constitucionalista e uma visão radical da soberania popular.

Na Europa, a Revolução Francesa havia assumido a tarefa de superar todo o regime político e social do Antigo Regime. O povo não poderia ser apenas o autor da Constituição, mas tinha de ser o soberano, sem se deixar travar pela Constituição. A visão radical da soberania popular ganha espaço.

De toda forma, punha-se o problema de como o povo se faria ouvir, de como a sua existência política se expressaria na sociedade.exercício da vontade suprema do povo é, então, reconhecido aos seus representantes no Legislativo. Sendo a expressão do povo soberano, o parlamen- to não poderia ser limitado por nenhuma regra, nem mesmo pela Constituição. Parlamento passa a ser a sede de defesa dos interesses do povo, e esses interesses tinham por vértice os valores da liberdade individual e da propriedade, que não encontravam amparo adequado sob o regime monárquico absolutista.

Sob o prisma da supremacia do Parlamento, o direito constitucional francês se desenvolveu de modo diverso ao controle judicial das normas, instituído nos Estados Unidos, e ao controle concentrado numa corte especial, que mais tarde foi adotado na maior parte dos países da Europa ocidental.

Canotilho (2002, p. 52), define a Constituição moderna como "a ordenação sistemática e racional da comunidade política através de um documento escrito no qual se declarem as liberdades e os direitos e se fixam os limites do poder constituído". O mesmo doutrinador aduz que esse conceito deve ser visto sob o prisma do Estado Constitucional, ou Estado de direito, segundo o qual o poder estatal é exercido de forma soberana, tendo por destinatário e referente um povo reunido em um determinado território.

A Constituição, entendida como o alicerce sobre o qual se erige a ordenação jurídica de uma sociedade, também deve repousar sua validade em alguma base. De acordo com Branco e Mendes (2012, p. 117) "a Constituição não retira o seu fundamento de validade de um diploma jurídico que lhe seja superior, mas se firma pela vontade das forças determinantes da sociedade, que a precede". 
O fundamento da Constituição é, pois, o Poder constituinte originário, exercido pelo povo. Esse Poder originário é inicial, ilimitado e incondicionado; essas três características pressupõem a inexistência de qualquer ordenação ou condição anterior à Lei Fundamental, que, nas palavras de Bonavides (2004, p. 149), "obriga os poderes constituídos, mas não obriga o poder constituinte; ela institui o governo, distribui a competência, separa os poderes, arma-os de prerrogativas, mas não constitui a nação [...]", que é, deveras, seu fundamento ontológico.

Embora as constituições se pretendam eternas em essência, o poder constituinte originário não é capaz de prever todas as alterações conjecturais da sociedade no decorrer do tempo. Nesse norte, a fim de manter os preceitos insculpidos na Constituição em consonância com as necessidades e desejos da nação, o próprio Poder originário previu um Poder reformador, derivado daquele, destinado a fazer as adequações pertinentes.

\footnotetext{
Evita-se, desse modo, que o poder constituinte originário tenha de se manifestar, às vezes, para mudanças meramente pontuais. Reduzem-se os efeitos nefastos das contínuas rupturas da ordem constitucional.

Aceita-se, então, que a Constituição seja alterada, justamente com a finalidade de regenerá-la, conservá-la na sua essência, eliminando as normas que não mais se justificam política, social e juridicamente, aditando outras que revitalizem o texto, para que possa cumprir mais adequadamente a função de conformação da sociedade. (BRANCO; MENDES, 2012, p. 134)
}

Outro aspecto importante da supremacia da constituição é a sua estabilidade, definida pelo binômio rigidez-flexibilidade do texto magno. É que o Poder constituinte derivado tem de obedecer ao texto constitucional se quiser modificá-lo; daí, quanto mais complexo e denso for o procedimento para alterar a Carta Magna, mais rígida ela será.

Barroso (2012) corrobora essa assertiva e afirma que a rigidez constitucional é pressuposto para a existência e parâmetro do controle de constitucionalidade.

Para que possa figurar como parâmetro, como paradigma de validade de outros
atos normativos, a norma constitucional precisa ter um processo de elaboração
diverso e mais complexo do que aquele apto a gerar normas infraconstitucionais.
Se assim não fosse, inexistiria distinção formal entre a espécie normativa objeto
de controle e aquela em face da qual se dá o controle. Se as leis
infraconstitucionais fossem criadas da mesma maneira que as normas
constitucionais, em caso de contrariedade ocorreria a revogação do ato anterior e
não a inconstitucionalidade. (BARROSO, 2012, p. 24)

Rígida é constituição que exige processos, solenidades e exigências formais especiais para sua alteração ao aditamento. Na prática, é mais difícil de alterar a constituição do que leis ordinárias ou complementares. Por seu turno, uma Constituição flexível prescinde dessas 
solenidades especiais, podendo ser modificada pelo legislador segundo o mesmo processo de elaboração das leis ordinárias. $\mathrm{Na}$ verdade, a própria lei ordinária contrastante muda o texto constitucional. Branco e Mendes (2012) pensam que isso decorre do princípio de que a lei posterior revoga a anterior, mormente porque se perde a noção de hierarquia normativa.

Alheio às normativas que garantem a rigidez ou flexibilidade, ocorre, ainda, o fenômeno da mutação constitucional. Por mutação entende-se a mudança na interpretação dada ao texto, em alterá-lo em si. Por isso as normas e preceitos insculpidos no ordenamento constitucional são compreendidos, também, em diversos sentidos:

Em sentido formal, atende à questão da superioridade hierárquica decorrente de uma norma estar expressamente declarada na Constituição. Nesse viés, Palu (2001) ensina que independentemente do conteúdo, as normas contidas no texto constitucional estão no topo da pirâmide de Kelsen, pois tiveram um processo elaboração e modificação mais complexo.

No sentido material ou substancial a norma deposita seu status constitucional em seu conteúdo ou objeto. A Constituição em sentido material, segundo Branco e Mendes (2012), é um conjunto de normas que fixam e limitam as competências do Estado e garantem às pessoas uma posição fundamental ante o poder público (direitos fundamentais). O sentido abarca, por exemplo, os tratados internacionais que versem sobre direitos humanos, que gozam, materialmente, de status constitucional.

\section{CONTROLE JUDICIAL DE CONSTITUCIONALIDADE}

Necessária a análise de precedentes históricos de controle de constitucionalidade. A hierarquia de valores ou mandamentos surge antes da invenção da escrita. Cappelletti (1999) afirma que mesmo nos agrupamentos humanos mais primitivos, já organizados hierarquicamente, as ordens dos líderes valiam mais do que a vontade de seus subalternos. Depreende-se disso que a vida em sociedade é fundada na obediência a certos comandos e valores estipulados pela própria coletividade, ou, mais precisamente, por quem detém o poder.

O autor cita como primeiro registro histórico do controle de constitucionalidade os juramentos dos juízes atenienses na Grécia antiga. A Cidade-Estado de Atenas era regida pelas nómos (leis) e pelos pséfisma (regulamentos), sendo as primeiras preponderantes sobre os segundos. Embora os magistrados devessem julgar segundo as leis e segundo os 
regulamentos, também deviam observar a conformidade dos regulamentos segundo as leis, deixando de aplicá-los quando as contrariavam.

Cappelletti (1999) advoga, ainda, que o Direito romano manteve o modelo ateniense, mas ele entrou em decadência na Idade Média. No período medieval, as únicas balizas ao poder dos senhores feudais eram as leis naturais - de natureza divina -, que eram controladas pela Igreja.

Branco e Mendes (2012) consideram que a história constitucional foi reinaugurada pela Magna Carta de 1215; ela foi o primeiro documento que se impôs frente à vontade de um soberano, o Rei da Inglaterra. Surgiu daí a ideia segundo a qual não se aplicaria uma ordem do monarca caso contrariasse a Magna Carta.

Através da Revolução Gloriosa, em 1689, a Inglaterra mais uma vez foi pioneira e sujeitou definitivamente o poder da Coroa às leis aprovadas pelo Parlamento. Cem anos mais tarde, com a Revolução Francesa, também a França estabeleceu um modelo segundo o qual a vontade do povo manifestada no Poder Legislativo é soberana.

Após a Revolução Francesa, os juízes ainda estavam vinculados à monarquia e eram considerados, pois, adversários do Novo Regime. Assim, era inconcebível na Europa do século XVIII o controle judicial sobre a validade das leis.

Houve uma situação paradoxal na França depois da Revolução Francesa, pois embora os revolucionários tivessem estabelecido os ideais de liberdade, igualdade e fraternidade, bem como redigido a Declaração dos Direitos do Homem em 1789 e uma Constituição em 1791, não se tinha efetividade na constituição. Canotilho (2002, p. 96) ensina que "a supremacia da constituição foi neutralizada pela primazia da lei[...], sendo o Estado legal relativamente eficaz no cumprimento do princípio da legalidade administrativa, mas insensível à força normativa dos direitos e liberdades que alicerçavam sua Revolução".

A tradição norte-americana, fundada no common law, assenta o controle das suas leis, atos administrativos e decisões judiciais na própria Constituição dos Estados Unidos da América. Em contraposição à supremacia do Parlamento e dos ordenamentos britânicos frente a suas liberdades individuais, os norte-americanos, ao declararem sua independência e elaborar sua Constituição, tiveram a preocupação de restringir os Poderes do Estado - através dos denominados checks and balances, que garantem a independência e harmonia entre eles.

$\mathrm{Na}$ verdade, o texto da Constituição dos EUA não prevê expressamente de quem é a competência para o controle de constitucionalidade. Segundo Cappelletti (1999), entretanto, já 
estava consolidado o precedente de que eram nulas e inaplicáveis as leis coloniais que conflitassem com as ordenações do Reino da Inglaterra; sendo mantido o precedente quando as ordenações da metrópole foram substituídas pelas constituições estaduais e federal dos EUA.

Barroso (2012, p. 32), faz valiosa análise do caso Marbury v. Madison:

Marbury v. Madison, portanto, foi a decisão que inaugurou o controle de constitucionalidade no constitucionalismo moderno, deixando assentado o princípio da supremacia da Constituição, da subordinação a ela de todos os Poderes estatais e da competência do Judiciário como seu intérprete final, podendo invalidar os atos que lhe contravenham.

Barroso (2012) e Streck (2013), narram que em março de 1801, o presidente John Adams já sabia que ele e seu partido federalista haviam sido derrotados nas urnas pelo democrata Thomas Jefferson. Tendo isso em vista, nos últimos 16 dias de seu governo, o presidente Adams nomeou diversos de seus companheiros do partido federalista para ocupar 67 novos cargos de magistrados (juízes federais e de paz). Além disso, também nomeou e empossou o Secretário de Estado de seu governo, John Marshall, como juiz da Suprema Corte dos EUA. Esses últimos atos foram entendidos - e como de fato eram - como artimanhas para manter a influência partido federalista, que havia perdido as eleições, junto ao sistema político norte-americano.

Contudo, quando, enfim, Thomas Jefferson assumiu a presidência, ele ordenou ao novo Secretário de Estado, James Madison, que não desse posse aos juízes federais apontados pelo governo anterior sob alegação de que o ato do presidente Adams fraudava o sistema republicano.

Diante dessa negativa, um dos juízes escolhidos pelo ex-presidente Adams, Willian Marbury, resolve ajuizar na Suprema Corte um writ of mandamus (mandado de segurança) contra o ato do secretário Madison, buscando que o Judiciário reconhecesse seu direito ao cargo e obrigasse o Executivo a lhe empossar.

O mandamus de Marbury v. Madison era uma difícil decisão, não só do ponto de vista jurídico, mas, sobretudo, do político. Por ironia do destino, a decisão do caso cabia ao agora Chief Justice da Suprema Corte John Marshall (o mesmo Marshall que era secretário de Estado do governo Adams e que tinha participado dos eventos em cotejo). Para piorar a situação, Marshall não se deu por impedido; o que levou o presidente Jefferson a declarar ao Congresso americano que não empossaria Marbury mesmo que a Suprema Corte ordenasse. 
Marshall, enquanto juiz da Suprema Corte, solucionou o caso de modo brilhante, evitando que se instaurasse uma crise entre os Poderes e instituições republicanas. Na visão de Barroso (2012), a sentença de Marshall está dividida em três partes: na primeira, ele fundamenta o direito de Marbury ao cargo de juiz; a segunda parte advoga que o writ of mandamus é o remédio adequado para sanar o ato ilegal do Executivo; e, na terceira parte, Marshall analisa a competência originária da Suprema Corte para julgar esse mandamus.

O precedente fundante do controle judicial de constitucionalidade está na argumentação dessa terceira parte. O caso Marbury v. Madison foi ajuizado na Suprema Corte de acordo com a competência originária que lhe foi atribuída pela seção 13 do Judiciary Act de 1789. Ocorre que a Constituição dos Estados Unidos, no artigo III, traz expressamente as competências da Suprema Corte; dentre as quais não está a originária em mandado de segurança. A partir dessa divergência entre o que diz o Judiciary Act (uma lei ordinária) e a Carta Política, Marshall fundamenta sua decisão no sentido de que a Constituição deve prevalecer enquanto lei suprema e fundamental. Fundamenta mais: diz que cabe ao Judiciário, isto é, a todos os juízes investidos, reconhecer as incongruências das normas comuns com a Lei Maior e deixar de aplicá-las, ainda que não provocados explicitamente para tanto.

Destarte, Marshall concluiu que a seção 13 do Judiciary Act, que ampliou as atribuições da Suprema Corte, não é compatível com a Constituição dos EUA, devendo, por isso, ser desconsiderada; logo, não cabia mais àquele Tribunal julgar o writ of mandamus originariamente. Hodiernamente, isso equivaleria a extinguir o processo sem resolução do mérito, ou baixá-lo à primeira instância. Mas isso pouco importa. Com essa decisão, o Chief Justice Marshall evitou sérios atritos entre Executivo, Legislativo e Judiciário e, sobretudo, conferiu a este último o poder de controlar a constitucionalidade das leis. A fixação do judicial review é, pois, o grande precedente firmado pela Suprema Corte naquela decisão de 1803 e que vale até hoje.

O citado caso foi consagrado como um dos precedentes-base do Direito norteamericano. Depreende-se daí que o Judiciário somente analisa a constitucionalidade das normas quando provocado em um caso prático, em que haja litigantes - cabendo às partes alegarem a dita inconstitucionalidade para fundar ou refutar seu direito.

O Poder Judiciário tem competência para julgar disputas atuais que se promovam entre litigantes diversos. O direito de declarar inconstitucionalidade das leis surge porque uma 
delas, invocada por uma das partes como fundamento do seu direito, está em conflito com a lei fundamental.

A doutrina entende que mesmo atualmente é vedado ao judiciário dos EUA conhecer da validade in abstrato das normas, justamente porque dotam o modelo difuso puro. Assim se traduz o fundamento pelo qual os juízes deixam de aplicar uma norma inconstitucional:

\begin{abstract}
Essa faculdade, que é o dever mais importante e dedicado da Corte, não lhe é atribuída como um poder de revisão da obra legislativa, mas porque os direitos dos litigantes nas controvérsias de natureza judicial requerem que a Corte opte entre a lei fundamental e a outra, elaborada pelo Congresso na suposição de estar em consonância com sua experiência constitucional, mas que, na verdade, exorbita do poder conferido ao ramo legislativo do governo. Essa tentativa para conseguir a declaração judicial de validade da lei elaborada pelo Congresso não se apresenta, na hipótese, em um caso ou controvérsia, a cuja apreciação está limitada a jurisdição desta Corte, segundo a lei suprema dos Estados Unidos. (BITTENCOURT apud MELO FILHO, 2008, p. 8).
\end{abstract}

Clève (2000) aduz que no controle difuso previsto pelo Direito brasileiro a questão constitucional pode ser argumentada pelo autor na petição inicial de uma ação de qualquer natureza (civil, trabalhista, eleitoral), proposta perante qualquer órgão jurisdicional, desde que competente para a causa (inclusive os Tribunais nos casos de competência originária), pelo réu por ocasião da resposta (contestação, reconvenção, exceção), ou, ainda por aquele que na qualidade de terceiro integra a relação processual.

Não obstante, a alegação de inconstitucionalidade pode ser deduzida nas ações constitucionais, inclusive no mandado de segurança, no habeas corpus e no habeas data, podendo também ser suscitada na ação civil pública e na ação popular.

Veloso (2003) sublinha que no controle difuso a discussão acerca da constitucionalidade da norma não é o cerne da demanda, mas, sim, questão prejudicial sobre a qual as partes podem fundar seu direito ou refutar uma obrigação. Aliás, considerando o caráter de interesse público da questão constitucional, também pode o juiz reconhecê-la de ofício. Daí ser o controle difuso caracterizado como incidental - um incidente no litígio para decidir se uma norma será aplicada ou não. Consectário desse modelo é o efeito inter partes do controle difuso, isto é, a declaração valerá apenas para o caso concreto e entre aquelas partes.

Streck (2013, p. 508-509) resume, assim, as características do controle difuso:

O Poder Judiciário só se pronuncia em face de um caso concreto, para cuja decisão seja mister o exame da constitucionalidade da lei aplicável à espécie;

- presumem-se constitucionais os atos do Congresso;

- na dúvida, decidir-se-á pela constitucionalidade; 
- o juiz deve abster-se de se manifestar sobre a inconstitucionalidade, toda vez que, sem isso, possa julgar a causa e restaurar o direito violado;

- sempre que possível, adotar-se-á a exegese que torne a lei compatível com a Constituição;

- a tradicional aplicação dos princípios constantes de uma lei, sem que se ponha em dúvida sua constitucionalidade, é elemento importante no reconhecimento desta;

- não se declaram inconstitucionais os motivos da lei. Se esta, no seu texto, não é contrária à Constituição, os tribunais não lhe podem negar eficácia;

- na apreciação da inconstitucionalidade, o Judiciário mão se deixará influenciar pela justiça, conveniência ou oportunidade do ato do Congresso;

- se, apenas, algumas partes da lei forem incompatíveis com a Constituição, estas será declaradas ineficazes, sem que fique afetada a obrigatoriedade dos preceitos sadios; e

- a inconstitucionalidade é imprescritível, podendo ser declarada em qualquer tempo.

O Brasil, atualmente, adota um modelo misto de controle de constitucionalidade, que reúne características dos modelos preventivo, difuso e concentrado.

\section{NEOCONSTITUCIONALISMO E O RELATIVISMO DAS DECISÕES JUDICIAIS}

As constituições que vigoram atualmente reúnem funções fundamentais: a noção de poder constituinte se associa ao conceito de legalidade constitucional, limitando o legislador; a Carta, nesse diapasão, erige-se como moldura normativa onde impera o princípio do pluralismo, através do qual são estabelecidas regras democráticas e princípios que regerão a vida em sociedade. Ao mesmo tempo em que as constituições limitam o legislador - vez que o texto constitucional deve ser respeitado -, ainda, são normas dirigentes fundamentais. (ARIZA, 2003).

Conforme o mesmo autor, dentre as repercussões mais significativas dos textos constitucionais destacam-se as que têm a ver com a condição normativa garantida e com as características do seu teor, nele insertos direitos, princípios, diretrizes e valores. Ao vislumbrar a constituição como uma norma, existem implicações nas funções jurisdicional e legislativa do Estado: ambas são pautadas pela normatização constitucional, em que pese a função jurisdicional poder ser mais amplificada diante de interpretações mais abrangentes.

O termo "neoconstitucionalismo" é comumente associado ao constitucionalismo contemporâneo e embora vários doutrinadores aceitem o modelo como atualmente vigente no Brasil, não existe um conceito uníssono. O entendimento de Ingo Wolfgang Sarlet não se coaduna com as lições apresentadas por Lênio Luiz Streck, por exemplo. Enquanto que o primeiro admite o uso de técnicas de interpretação do texto constitucional, o segundo "se mostra contrário ao emprego de qualquer método de interpretativo". (GALVÃO, 2014, p. 56). 
Enquanto que uma corrente entende que o neoconstitucionalismo seria um novo paradigma tanto na teoria quanto na prática dos tribunais, outros defendem que "o que a doutrina tem designado de Neoconstitucionalismo, em princípio, não substancia, organicamente, em nova teoria constitucional" (Galvão, 2014, p. 57).

O conceito de neoconstitucionalismo pode ser compreendido como sendo uma ou mais teorias que proporcionam cobertura justeórica de conceito e/ou de norma para a constitucionalização dos direitos em termos não positivos. (FIGUEROA, 2007). Por sua vez, Agra (2008), partindo da ideia de "Constituição como valor em si mesma", destaca que o escopo do neoconstitucionalismo é a concretização das prestações materiais prometidas à sociedade. Dentre suas principais pretensões e características poderiam ser mencionadas: a) positivação e concretização de um catálogo de direitos fundamentais; b) onipresença dos princípios e das regras; c) novos métodos hermenêuticos; d) densificação da força normativa do Estado; e) desenvolvimento da justiça distributiva.

Schier (2005, p. 9) arremata com as seguintes características: (i) maior presença da constituição em detrimento da lei; (ii) maior presença do juiz em detrimento do legislador; (iii) maior participação dos princípios em detrimento das regras; (iv) mais ponderação e menos subsunção; (v) vinculação do Estado à Constituição como "limitação", mas também como "prestação" e legitimação material; (vi) maior heterogeneidade axiológica dos textos constitucionais e, logo, mais pluralismo; (vii) aproximação entre direito e moral; (viii) ênfase na substância, sem contudo abandono da forma, do procedimento e, finalmente, (ix) eixo teórico fundado na teoria da argumentação sob perspectiva do pós-positivismo. $\mathrm{O}$ neoconstitucionalismo como ideologia possui alguns níveis ou versões: o filosófico-político considera o Estado constitucional de Direito como sendo a forma de organização política mais justa e melhor; a vinculação entre o Direito e a moral, o que impõe, naturalmente, a obrigação de respeito ao Direito; e, por fim, a adoção de um ponto de vista do jurista comprometido, sendo o seu trabalho e sua interpretação da constituição crítico e não puramente descritivo. Essas características, em maior ou menor extensão, foram identificadas por Dworkin, Habermas, Alexy, Nino, Zagrebelsky e Ferrajoli, por exemplo.

De acordo com Pozzolo (2003), o neoconstitucionalismo tem como objeto especificado a análise de ordenamentos constitucionais e democráticos. A autora complementa a ideia dizendo que o argumento do neoconstitucionalismo: "parte do dado positivo da constituição do bill of rights e da judicialização da carta fundamental. A partir 
disso negar a tese juspositivista da separação conceitual entre direito e moral". (POZZOLO, 2003, p. 198).

De acordo com Galvão (2014), desde 2003 o neoconstitucionalismo tem pautado inúmeros debates na academia brasileira. Segundo ele, baseado nos ensinamentos de Luís Roberto Barroso, a elaboração de um novo direito constitucional ou de uma nova cultura jurídica capaz de explicar, justificar e fomentar a intromissão por parte dos Tribunais em questões que até então ficavam restritas ao teatro político, tais como, por exemplo, as pesquisas com células tronco, o casamento entre pessoas do mesmo sexo e o aborto.

Ministros da Suprema Corte brasileira utilizam o vocábulo para designar o novo paradigma do direito constitucional brasileiro. O decano Celso de Mello que referiu o neoconstitucionalismo no julgamento histórico que reconheceu a união entre pessoas do mesmo sexo como sendo uma entidade familiar:

A força normativa de que se acham impregnados os princípios constitucionais e a
intervenção decisiva representada pelo fortalecimento da jurisdição constitucional
exprimem aspectos de alto relevo que delineiam alguns dos elementos que compõem
o marco doutrinário que confere suporte teórico ao Neoconstitucionalismo, em
ordem a permitir, numa perspectiva de implementação concretizadora, a plena
realização, em sua dimensão global, do próprio texto normativo da Constituição.
(BRASIL, RE 477554/MG* RELATOR: Min. Celso de Mello).

Referido julgamento reconhece o neoconstitucionalismo como sendo capaz de legitimar a interpretação construtiva de legislações, a qual se ampara, fundamentalmente, em princípios. Essa conjuntura, entretanto, abre caminho para a possibilidade de decisões judiciais promoverem o relativismo do texto constitucional em nome da salvaguarda de interesses e pretensões ainda que não expressos/permitidos pelo texto legal, mas que se amparam em uma dimensão principiológica. Nesse diapasão, ocorre uma relativização de normas e princípios para garantir interpretações favoráveis ou desfavoráveis em determinada ação (MENDES JÚNIOR, 2019).

Ferrajoli (2012) critica o neoconstitucionalismo dizendo que a expressão mostra-se equivocada e ambígua, pois o vocábulo constitucionalismo pertence ao léxico político e designa uma ideologia que está ligada à tradição liberal, cujas raízes permeiam o jusnaturalismo. Streck (2014) também faz uma critica contundente ao neoconstitucionalismo ao afirmar que o modelo contribuiu para fragmentação das decisões em âmbito judicial: "direito possui DNA; os julgamentos não devem ser feitos a partir das apreciações subjetivas (valorativas, ideológicas, etc) dos julgadores". (STRECK, 2014, texto digital). 
O fato comum verificado empiricamente neste modelo é que os julgadores, sob o argumento de estarem aplicando princípios que emanam da Carta Magna (os quais, muitas vezes, em verdade, emanam de suas convicções pessoais e ideológicas) deixam de aplicar determinada norma que se aplicaria ao caso sub judice. Nesse diapasão, para além da insegurança jurídica, cria-se um cenário para o exercício arbitrário do controle incidental/difuso de constitucionalidade. Isso tudo acarreta a instalação de uma "justiça lotérica"2 (STRECK, 2009), diretamente relacionada ao relativismo das decisões judiciais.

\section{O MODELO GARANTISTA}

O constitucionalismo garantista é um novo paradigma juspositivista da democracia e do direito. Pode, de acordo com Ferrajoli ser definido como:

Um sistema jurídico e/ou uma teoria do direito que prevêem - para a garantia
daquilo que vem estipulado constitucionalmente como vinculante e inderrogável
- a submissão ( inclusive) da legislação a normas relativas à produção não só
formais, relativas aos procedimentos (ao quem e ao como), mas também
materiais, relativas aos conteúdos das normas produzidas (ao que se deve
decidir e ao que não se deve decidir), cuja violação gera antinomias, por
comissão, ou lacunas, por omissão. (FERRAJOLI, 2012, p. 18).

Esse constitucionalismo é caracterizado por uma força normativa regulativa em que a maior parte dos princípios constitucionais fundamentais são regras proibitivas de lesão ou são a garantia de prestação de garantias previstas constitucionalmente. (FERRAJOLI, 2012).

Conforme o mesmo estudioso:

Completa, enquanto positivamente normativo nos confrontos da própria normatividade positiva e enquanto sistema de limites e de vínculos substanciais relativos ao "quê", em acréscimo àqueles somente formais relativos ao "quem" e ao "como" das decisões, o velho modelo paleo-jus-positivista. Graças a ele, os princípios ético-políticos através dos quais eram expressos os velhos "direitos naturais" foram positivados, convertendo-se em princípios jurídicos vinculantes nos confrontos de todos os titulares de funções normativas: não mais como fontes de legitimação somente externa ou política, conforme o tradicional pensamento político liberal, mas também como fontes de legitimação e, sobretudo, de deslegitimação interna ou jurídica, que designam a razão social daqueles artifícios que, na verdade, são o Direito e o Estado Constitucional de Direito. (FERRAJOLI, 2012, p. 26).

\footnotetext{
${ }^{2}$ A designação 'lotérica' deve-se à distribuição dos processos por sorteio. Assim, haveria um componente 'sorte' para designação de um julgador favorável num sistema judiciário em que situações fáticas idênticas podem ter desfechos completamente diferentes, dependendo da interpretação/condução do magistrado na instrução ou na prolação da decisão.
} 
Esse modelo de constitucionalismo pressupõe que os princípios de caráter político e ético que consubstanciavam o direito natural tenham sido positivados, causando sua transmutação em princípios jurídicos, os quais não são fontes externas ao sistema jurídico, mas sim uma legitimação interna, já que eles integram o Estado Constitucional ou o Estado de Direito. (FERRAJOLI, 2012).

Para o mesmo doutrinador as principais diferenças entre o Constitucionalismo nãopositivista (também chamado de principialista) e o Constitucionalismo garantista são: "a) a conexão entre direito e moral; b) a distinção qualitativa e contraposta entre princípios e regras; c) a função da ponderação como oposição à subsunção na prática jurisdicional". (FERRAJOLI, 2012, p. 27).

Ferrajoli concorda que existe a possibilidade de haver uma indeterminação concernente à linguagem legal que possibilita uma "discricionariedade interpretativa", em que "o intérprete é, frequentemente, orientado por escolhas de caráter moral" (FERRAJOLI, 2012, p. 27). A dimensão principal da democracia constitucional é baseada nos direitos fundamentais que são direitos de todos e que condicionam além da validade, a coerência do direito positivo. (FERRAJOLI, 2012, p. 23).

Alexandre Morais da Rosa ensina que:

A Constituição é uma disposição fundante da convivência e fonte da legitimidade estatal, não sendo vazio, mas uma coalizão de vontades com conteúdo materializado pelos Direitos Fundamentais. A história do constitucionalismo é a progressiva ampliação da esfera pública de direitos, de conquistas e rupturas. Em outras palavras, a Constituição, nessa concepção garantista, deixa de ser meramente normativa (formal), buscando resgatar o seu próprio conteúdo formador, indicativo do modelo de sociedade que se pretende e de cujas linhas as práticas jurídicas não podem se afastar. (ROSA, 2011, p. 14-15).

Ferrajoli esclarece:

O garantismo não é concebível fora do horizonte teórico do positivismo jurídico, uma vez que parte da distinção do vigor das normas, tanto na sua validade quanto de sua efetividade, essencial para compreender a estrutura normativa do Estado de direito, caracterizado: a) por pertencerem as normas vigentes a níveis diversos e hierarquicamente ordenados, cada um dos quais se configura como normativo respectivamente àquele inferior, e como fático, respectivamente àquele superior; b) pela incorporação das normas superiores das obrigações e vedações que disciplinam a produção das normas inferiores, e cuja observação é condição da efetividade das primeiras e validade das segundas; c) pelas antinomias produzidas pelas violações das normas superiores por parte das inferiores, e pelo simultâneo vigor de umas, ainda que não efetivas, e de outras, ainda que inválidas; d) pela consequente ilegitimidade jurídica que investe sempre os poderes normativos, legislativo e judiciário, e que é tanto maior quanto mais ampla não efetiva é a incorporação limitativa dos deveres nos níveis mais altos do ordenamento. (FERRAJOLI, 2006, p. 804) 
Nesse sentido, de acordo com (ROSA, 2011, p. 5): "(...) diante da complexidade contemporânea a legitimação do Estado Democrático de Direito deve suplantar a mera democracia formal, para alcançar a democracia material, na qual os Direitos Fundamentais devem ser respeitados (...)".

Ferrajoli (2012) acredita que o Constitucionalismo principialista promove uma aproximação, manifestamente inadequada, entre direito e moral. Para ele, o constitucionalismo garantista é o mais adequado, na medida em que os princípios são incorporados às leis e Constituições.

Destaca-se que ao passo em que o constitucionalismo garantista pressupõe uma separação entre legitimação externa e interna como a distinção de validade e justiça, de direito e moral; correntes neoconstitucionalistas condicionam a legitimação interna à externa, fazendo com que a moral seja vista como ponto de vista interno ao direito. (ABREU; ABREU, 2016).

\section{CONSIDERAÇÕES FINAIS}

Atualmente o Direito vive uma fase de verdadeiro constitucionalismo. A interpretação das normas pretende-se fazer para além da fria letra da lei; aliás, de acordo com os princípios da hermenêutica, é necessário que se interprete o sistema jurídico como um conjunto interdepende e harmônico de normas e valores.

Constituição é o documento que fundamenta a existência do próprio Estado, definindo e limitando seus Poderes. Por tais funções essenciais, a Constituição expressa a soberania de um povo (ou, às vezes, de quem detém o poder). Em razão disso, no que guarda respeito a hierarquia de normas, a Carta Magna estará no topo, emanando princípios e normas para orientar todo o sistema jurídico adjacente. Dessa posição privilegiada decorre a supremacia da Constituição.

O controle de constitucionalidade busca garantir a harmonia e coerência do sistema jurídico com base na supremacia da Constituição. O controle nada mais é do que uma relação de comparação entre uma norma infraconstitucional, que pode ser uma lei, um decreto e até mesmo um tratado internacional, com o texto da própria Constituição. Se não forem detectadas incompatibilidades, a lei será constitucional e estará apta a produzir seus efeitos 
normalmente; porém, identificado um ponto em que afronta uma disposição da Lei Maior, esta última deverá prevalecer.

Assim, o presente artigo buscou definir o constitucionalismo e apresentar a supremacia da Constituição; analisar o controle judicial de constitucionalidade; o neoconstitucionalismo e, por fim, o constitucionalismo garantista.

O objetivo geral do trabalho estava centrado na análise do instituto do controle de constitucionalidade no ordenamento jurídico brasileiro, bem como descrever o neoconstitucionalismo e o constitucionalismo garantista. Assim, diante da análise do problema proposto para este estudo - se existe a possibilidade de utilização de argumentos não jurídicos e, ainda, não legislados para decidir na seara processual? -, pode-se concluir que a hipótese inicial levantada para tal questionamento é verdadeira.

Acredita-se que com o neoconstitucionalismo há a possibilidade de uma leitura amplamente aberta do texto constitucional e existe a possibilidade de utilização argumentativa que foge dos argumentos jurídicos utilizados costumeiramente quando da prolação de decisões judiciais. Com isso ocorre uma nítida desconstrução do próprio sistema judiciário, pois alguns magistrados utilizam o poder discricionário, por vezes cabível, para decidir as lides que lhe são submetidas para apreciação conforme suas convicções particulares, desdenhando ao que refere a legislação ou a constituição e imperando o senso de justiça do próprio julgador que precisa se ater aos anseios da sociedade, bem como às necessidades temporais.

Verifica-se que isso até pode funcionar enquanto se tem uma composição ou um juiz Hércules, mas esse poder atribuído ao Judiciário, na figura do magistrado, pode se voltar contra os direitos fundamentais e contra as minorias. A mesma discricionariedade judicial que permitiu o casamento entre pessoas do mesmo sexo quando a Constituição dispõe que é entidade familiar a união "entre o homem e a mulher" (art. $226, \S 3^{\circ}$ ) é a que permitiu a execução provisória da pena depois da segunda instância quando a Carta Magna fala que "ninguém será considerado culpado até o trânsito em julgado de sentença penal condenatória" (art. $5^{\circ}$, LVII). O casamento entre pessoas do mesmo sexo proporcionou uma ampliação da possibilidade de contrair matrimônio, beneficiando todos aqueles que possuem relações homoafetivas e que tinham vontade de oficializar a relação através do casamento. Contudo, a decisão que permitiu a prisão antes do trânsito em julgado levou para carceragem milhares de pessoas que, quiçá, ao final sequer teriam a condenação mantida. 
É nítido que a soma do controle de constitucionalidade com o neoconstitucionalismo tem como resultado a possibilidade de relativismo das decisões judiciais. Nesse contexto, o modelo de constitucionalismo garantista emerge como uma opção adequada, pois observa princípios fundamentais como regras que proíbem lesões e determinam a aplicação das garantias previstas no texto constitucional expresso. Evita-se, assim, que decisões sejam relativizadas a depender das partes ou do julgador, culminando em um ambiente de maior segurança jurídica.

\section{REFERÊNCIAS:}

ABREU, Ana Claudia da Silva; ABREU, Guilherme Schroeder. Constitucionalismo Garantista X Neoconstitucionalismo: Limite à Discricionariedade Judicial. Revista Teorias do Direito e Realismo Jurídico. Brasília: 2016. p. 43-65.

AGRA, Walber de Moura. Curso de direito constitucional. 4. ed. rev. e atual. Rio de Janeiro: Forense, 2008.

ARIZA, Santiago Sastre: La Ciencia Jurídica Ante el Neoconstitucionalismo, in: Neoconstitucionalismo (s). Madrid: Trotta, 2003, p. 239-258

BARROSO, Luis Roberto. O controle de constitucionalidade no Direito brasileiro: Exposição sistemática da doutrina e análise crítica da jurisprudência. 6. ed. São Paulo: Saraiva, 2012. Ebook. Disponível em: <http://online.minhabiblioteca.com.br/\#/books/ 9788502170360>. Acesso em: 24 out. 2019.

BASTOS, Celso Ribeiro. Curso de teoria do Estado e ciência política. 5. ed. São Paulo: Celso Bastos, 2002.

BONAVIDES, Paulo. Curso de direito constitucional. 16. ed. São Paulo: Malheiros, 2004.

BRANCO, Paulo Gustavo Gonet; MENDES, Gilmar Ferreira. Curso de Direito

Constitucional. 7. ed. São Paulo: Saraiva, 2012.

BRASIL. Supremo Tribunal Federal. RE 477554/MG* RELATOR: Min. Celso de Mello. União Estável Homoafetiva - Legitimidade Constitucional - Afeto como Valor Jurídico Direito à Busca da Felicidade. Disponível em: < http://www.stf.jus.br/portal/informativo/verInformativo.asp?s1=ADI+1923\&pagina=2\&base= INFO>. Acesso em 06 nov. 2019.

CANOTILHO, José Joaquim Gomes. Direito Constitucional e Teoria da Constituição. 6. ed. Coimbra: Almedina, 2002.

CAPPELLETTI, Mauro. O controle judicial de constitucionalidade das leis no direito comparado. 2. ed. Porto Alegre: Sergio Antonio Fabris, 1999.

Revista Brasileira de Teoria Constitucional| e-ISSN: 2525-961X | Encontro Virtual | v. 6 | n. 2 | p. 59 - 79 | Jul/Dez. 2020. 
CLÈVE, Clèmerson Merlin. A fiscalização abstrata da constitucionalidade no Direito brasileiro. São Paulo: Revista dos Tribunais, 2000.

FERRAJOLI, Luigi. Direito e razão: teoria do garantismo penal. 2. ed. São Paulo: Editora Revista dos Tribunais, 2006.

FERRAJOLI, Luigi. Constitucionalismo principialista e constitucionalismo garantista. Tradução de A. K. Trindade. In: Garantismo, hermenêutica e (neo)constitucionalismo. Porto Alegre: Livraria do Advogado, 2012.

FIGUEROA, Alfoso Garcia. A teoria do direito em tempos de constitucionalismo. Revista Brasileira de Estudos Constitucionais [recurso eletrônico], Belo Horizonte, v. 1, n. 4, p. 77 102, out./dez. 2007.

GALVÃO, Jorge Lavocat. O neoconstitucionalismo e o fim do estado de direito $1^{\mathrm{a}}$ ed. São Paulo: Saraiva, 2014.

MELO FILHO, João Aurino de. Modelos de controle de constitucionalidade no direito comparado. Influências no sistema de controle de constitucionalidade brasileiro. Jus Navigandi, Teresina, ano 13, n. 1753, 19 abr. 2008. Disponível em: <http://jus.com.br/artigos/11158>. Acesso em: 24 out. 2019.

MENDES JÚNIOR, Frederico. A magistratura de hoje e a pós verdade: Relativismos e a decisão judicial. Revista Justiça \& Cidadania. 2019. Disponível em: <

https://www.editorajc.com.br/a-magistratura-de-hoje-e-a-pos-verdade-relativismos-e-adecisao-judicial/>. Acesso em: 10 dez. 2020.

MEZZAROBA, Orides; MONTEIRO, Cláudia S. Manual de metodologia da pesquisa no Direito. 5. ed. São Paulo: Saraiva, 2009.

MORAIS, José Luis Bolzan de; STRECK, Lenio Luiz. Ciência política e teoria geral do Estado. 5. ed. Porto Alegre: Livraria do Advogado, 2006.

PALU, Oswaldo Luiz. Controle de constitucionalidade: conceitos, sistemas e efeitos. 2. ed. São Paulo: Revista dos Tribunais, 2001.

POZZOLLO, Susanna. Um Constitucionalismo Ambíguo. In: CARBONELL, Miguel. Neoconstitucionalismo(s). Trotta: Madrid, 2003.

ROSA, Alexandre Morais da. Garantismo jurídico e controle de constitucionalidade material: aportes hermenêuticos. 2. ed. Rio de Janeiro: Lumen Juris, 2011.

SANCHÍS, Luis Prieto. Neoconstitucionalismo e ponderação judicial. In: CARBONELL, Miguel (Org.). Neoconstitucionalismo (s). Madrid: Trotta, 2003. p. 123-158.

SCHIER, Paulo Ricardo. Direito Constitucional: anotações nucleares. Curitiba: Juruá, 2005. 
STRECK, Lênio Luiz. Jurisdição constitucional e decisão jurídica. 3. ed. São Paulo: Revista dos Tribunais, 2013.

STRECK, Lênio Luiz. Jurisdição constitucional e hermenêutica: uma nova crítica do direito. 2. ed. São Paulo: Forense, 2004.

STRECK, Lênio Luiz. Eis porque abandonei o "neoconstitucionalismo". Consultor Jurídico: 2014. Disponível em: <https://www.conjur.com.br/2014-mar-13/senso-incomumeis-porque-abandonei-neoconstitucionalismo\#_ftn1_4781. Acesso em 07 nov. 2019.

STRECK, Lênio Luiz . Justiça Lotérica: ativismo judicial não é bom para a democracia. Entrevista. [15 de março de 2009]. Porto Alegre: Revista Consultor Jurídico. Entrevista concedida a Aline Pinheiro. Disponível em: <http://www.conjur.com.br/2009-mar15/entrevista-lenio-streck-procurador-justica-rio-grande-sul\#author, > . Acesso em 04 nov. 2019.

STRECK, Lênio Luiz. TRINDADE, André Karam (orgs.). Garantismo, hermenêutica e (neo)constitucionalismo: um debate com Luigi Ferrajoli. Porto Alegre: Livraria do Advogado, 2012. p. 13-56.

VELOSO, Zeno. Controle jurisdicional de constitucionalidade: atualizado conforme as leis 9.868 de 10.11.1999 e 9.882 de 03.12.1999. 3. ed. Belo Horizonte: Del Rey, 2003. 